\title{
The Direct and Indirect Effects of a Global Pandemic on US Fishers and Seafood Workers
}

\author{
Easton White ${ }^{1,2^{*}}$, Jill Levine ${ }^{3}$, Amanda Moeser ${ }^{4}$, Julie Sorensen ${ }^{5}$ \\ ${ }^{1}$ Department of Biological Sciences, University of New Hampshire, Durham, NH, 03824 \\ ${ }^{2}$ Gund Institute for Environment, University of Vermont, Burlington, VT, 05482 \\ ${ }^{3}$ Department of Biology; Department of Forestry, University of Vermont, Burlington, VT 05401 \\ ${ }^{4}$ Environmental Studies Department, Antioch University New England, Keene, NH, 03431 \\ ${ }^{5}$ Northeast Center for Occupational Health and Safety: Agriculture, Forestry and Fishing, Bassett \\ Healthcare Network, Cooperstown, New York, 13326 \\ *Corresponding Author: Easton White (Easton.White@unh.edu) \\ 38 Academic Way, Durham, New Hampshire, 03824, USA
}

\begin{abstract}
The United States' seafood industry experienced major shifts in consumer demand and COVID-19 socialdistancing restrictions starting in March 2020, when the early stages of the pandemic were unfolding. However, the specific effects on workers across seafood value chains are less well known. According to the US Centers for Disease Control and Protection (CDC), fishers and seafood workers face an increased risk of workplace exposure to COVID-19 given the close proximity to others in processing facilities and on fishing vessels, long work hours, and communal housing, living, and transportation arrangements associated with seasonal employment. To explore this hypothesis, and given a lack of data on the sector, we reviewed news articles, scientific articles, and white papers to identify the various effects of COVID19 on US seafood workers and to track COVID-19 cases and outbreaks. Here, we show that most COVID-19 cases among seafood workers were reported during the summer of 2020 and during the beginning of 2021 with outbreaks primarily occurring in seafood processing. COVID-19 cases were documented throughout coastal areas, with Alaska experiencing the largest number of cases and outbreaks. Based on news reports, seafood workers were about twice as likely to contract COVID-19 as workers in other parts of the overall US food system. By examining news articles and scientific literature, we also documented several indirect effects of the pandemic. Social-distancing restrictions limited crew size and number of workers on processing lines, resulting in longer work hours and more physical and mental taxation. Economic consequences of the pandemic were reportedly a primary concern for fishers and aquaculture businesses, including changes in markets, supply, and demand, in addition to revenue loss, price fluctuations, supply chain issues, and labor shortages. Fewer outlets interviewed workers in seafood processing; however, concerns about workplace safety, contracting COVID-19, access to medical services, vaccination, and paid sick leave were all noted. We also highlight several inequities in COVID19 responses within the seafood sector, both along racial and gender lines. Peer-reviewed studies and news coverage all point to diverse direct and indirect effects of the COVID-19 pandemic on workers across seafood value chains. The summary of these effects can serve as a foundation for future work on infection control and occupational outreach to workers in the seafood sector.
\end{abstract}

Keywords: COVID-19, seafood worker, fisheries, seafood value chains, workplace safety 


\section{Introduction}

The seafood industry is well-known for its high rates of occupational injury and fatality. While occupational health has not been as widely explored as work-related injuries have in this sector, several articles have indicated that work-related illness is still a cause for concern for workers across seafood value chains. According to Sorensen et al. fatality rates, injuries, and comorbidities among fishing industry workers were reported to be higher than in other industries even before the spread of coronavirus in the U.S. (Sorensen et al., 2020). The average fatality rate among all US full time workers was 4 deaths per 100,000 from 2000-2017 compared to the US commercial fisher fatality rates of 114 deaths per 100,000 full-time workers in 2000-2017 (BLS, 2019). US Coast Guard and OSHA reports also indicate that the Alaskan seafood processing industry is "high-risk" for traumatic injuries (Syron et al., 2018). It was estimated that the fatality rate for seafood workers was 121 for every 100,000 . This is $34 \%$ higher than the average rate of all U.S. workers (Lucas et al., 2014). Coast Guard injury reports have underscored the need to prevent musculoskeletal injuries to the upper body and extremities, as more serious incidents (back injuries, intracranial injuries, finger crushing, amputations) can lead to disability. Post-traumatic stress disorder (PTSD) and its symptoms have also been reported by fishers and seafood workers, with some fisheries workers in the Northeast reporting significantly higher rates of PTSD than other U.S. workers. These symptoms include intrusive memories, anger, and irritability. Additionally, fishers endure a higher prevalence of sleep apnea, hearing loss, and musculoskeletal disorders, all having the potential to lead to addiction to pain medications and overdose deaths (Sorensen et al., 2020).

Several studies of the impact of the COVID-19 pandemic on the seafood sector, indicated that COVID had both direct impacts to health as well as indirect effects connected to reduced labor access and economic losses (Bennett et al., 2020; Knight et al., 2020; Love et al., 2021a; Ross et al., 2021; White et al., 2021). Even before the appearance of COVID cases in the US, overseas demand for seafood products dropped due to pandemic lockdowns in China (Gephart et al., 2020; White et al., 2021). With the worldwide spread of the pandemic, global demand for seafood was significantly reduced (FAO, 2020; Love et al., 2021a; White et al., 2021), greatly impacting U.S. fisheries given the country's position as a major trader of seafood (Gephart and Pace, 2015). In addition, pre-COVID, restaurants accounted for $65 \%$ percent of consumer expenditures for seafood (Love et al., 2020). Thus, social-distancing restrictions and onsite dining restrictions greatly affected demand for seafood products. An article published in the Washington Post during the pandemic reported a sales decline as high as $95 \%$ for US fisheries (Reiley, 2020). In a survey of 260 commercial fishers, authors found a considerable increase in fishers work hours as they attempted to switch to direct consumer sales (Smith et al., 2020). Declines in profit also led to smaller crews, which meant longer work hours for those still fishing. Forty-five percent of fishers who tried direct consumer marketing reported more than a 20\% decline in income (Sorensen et al., 2020).

With a loss of income, fishing boat captains likely had less money to invest in safety, which can increase the potential for hazardous exposures on fishing vessels. U.S. Coast Guard inspectors found a rise in safety violations on vessels from $10 \%$ to $30 \%$ in their district since the COVID-19 pandemic, as well as an increase in the number of boats sent back to port for unsafe conditions (Sorensen et al., 2020). Fishing and processing vessel crew quarters are tight spaces even on large ships. Crew members typically share sleeping quarters (bunk beds) and eating areas are communal by necessity. In these circumstances, social distancing is largely impossible and use of personal protective equipment, such as masks, is also problematic, given environmental conditions on fishing boats (wind, water, etc.). Vessels are often constantly wet and therefore make PPE less sanitary and more hazardous to human health due to the accumulation of bacteria from fish (Syron et al., 2018). The risk of COVID-19 outbreaks are significant in high-density workplaces, such as seafood processing plants. Alaska's seafood processing facilities attract almost 18,000 out-of-state workers every year. According to the state's reportable disease database (Porter et al., 2021), 667 cases of COVID-19 were identified among seafood processing workers. Onehundred and two of those cases were independent, occurring from either quarantine groups in or outside 
of the facilities, however, the remaining 539 cases were part of outbreaks that spread beyond quarantine groups, both within and outside of the facility. Six of the cases identified in the state's database did not have enough information to determine transmission details. These outbreaks led Alaskan state personnel and CDC field employees to increase COVID-19 restriction measures by mandating reductions in group gatherings to less than 10 individuals. These authorities also noted that "safe" transfer of crews midseason was an inadequate measure for preventing the spread of the virus, as there was an outbreak during the transfer of a crew from one processing facility to another (Porter et al., 2021). Entry testing and quarantining were found to help prevent the transmission of COVID-19 from processing plants and vessels.

While several peer-reviewed manuscripts have explored the impact of the global COVID-19 pandemic on the seafood sector, our goal was to document the spread of COVID-19 within the seafood sector and also highlight indirect effects of the pandemic on U.S. seafood workers. Specifically, we examine news articles and data on COVID-19 cases in the seafood industry to understand when and where COVID-19 cases occurred, both the indirect and direct effects of the pandemic throughout the seafood value chain, and how the seafood sector fared compared to similar industries.

\section{Materials \& Methods}

New articles

We examined news articles to see how the media was reporting on stories related to COVID-19 and the seafood industry. We describe a few specific case studies below, but we also examined reporting over time using the Global Database of Events, Language and Tone (GDELT) of news articles (GDELT, 2021). We restricted our search to articles published in the US from January 2020 to September 2021. Specifically, we examined the frequency of articles that included the terms (COVID) AND (worker OR employee) AND (seafood OR fisheries). This search criteria added up to 20,229 individual news articles, which includes articles that might be focused on the same event. This includes some articles published in the US about other countries as well as articles that might not focus on our specific topic. We did not filter articles beyond this point.

COVID-19 cases in the seafood industry

Throughout the COVID-19 pandemic, cases and outbreaks of COVID-19 among seafood workers were reported sporadically by news outlets (Douglas, 2021; Korban and Cherry, 2020; White et al., 2021). However, there were very few localities (e.g., local health department or hospital) that reported COVID19 cases broken down by industry or business. We used a compilation of news articles to build a database of cases within the seafood industry specifically. This was primarily facilitated using data collected by The Food \& Environment Reporting Network as well as articles we came across or collected previously (Douglas, 2021). The data includes cases and deaths among workers across all food systems, including seafood processors and fishers. The data also includes information on locations, industry, and company. We examined the number of cases and deaths among fishers and seafood processors throughout the COVID-19 pandemic. Specifically, we examined how cases varied over time, by location, and across the seafood value chain. We also compared how caseloads in the seafood industry compared to other related industries, such as farming and meatpacking. Specifically, we used information from the U.S. Bureau of Labor Statistics on the number of workers employed in Food Manufacturing (NAICS 311000) and the sub-category Seafood Product Preparation and Packaging (NAICS 311700) to supplement data captured in news coverage. Food Manufacturing includes a wide array of sectors, including meat processing, food manufacturers in factories, and seafood packaging. The employment numbers also include everything from top executives to front line workers. Seafood Product Preparation and Packaging includes fish butchers and processors. 


\section{Results}

News articles

Between March 2020 and September 2021, we identified a total of 1161 US news articles that specifically mentioned (COVID) AND (worker OR employee) AND (seafood OR fisheries) (Fig. 1). We found that most of the news coverage around COVID-19 and seafood workers occurred during the beginning of the pandemic and in early 2021 (Fig. 1). The coverage mostly included information on migrant seafood workers, vaccination campaigns, and outbreaks. The coverage also included articles focused on new policies implemented to combat the pandemic, such as financial assistance programs, limits on personnel on vessels, or new personal protective equipment (PPE) requirements. In May 2020, sole proprietors, fishers, and some contract workers became eligible to apply for a new federal Pandemic Unemployment Assistance (PUA) program designed to extend unemployment benefits to self-employed workers ("Maine Coast Fishermen's Association," 2021). In addition, \$300 million was awarded to states, tribes, and territories with inland and coastal fisheries to provide relief funds, including direct payments, to fisheries and aquaculture participants through the Coronavirus Aid, Relief, and Economic Security Act (CARES Act) (NOAA, 2021). At the same time, in June 2020, the CDC, OSHA, and FDA reported that seafood processing workers were at increased risk of exposure to COVID-19 and published an interim guidance document with specific recommendations on protecting seafood workers from COVID-19 (OHS, 2020); however, relief programs designed to reimburse seafood processing companies for investments in workplace health and safety were not announced until the following year and funds have yet to be distributed to seafood processors. In September 2021, USDA announced $\$ 650$ million in funding to support the Pandemic Response and Safety Grant program, which includes eligible seafood processing facilities and vessels, and $\$ 50$ million in additional funds available to seafood processors to enhance workplace safety measures, retrofit facilities, provide PPE, and cover medical costs associated with COVID-19 such as vaccination, testing, and paid sick leave (USDA, 2021). In September 2021, some seafood companies also started requiring workers to be vaccinated for COVID-19.

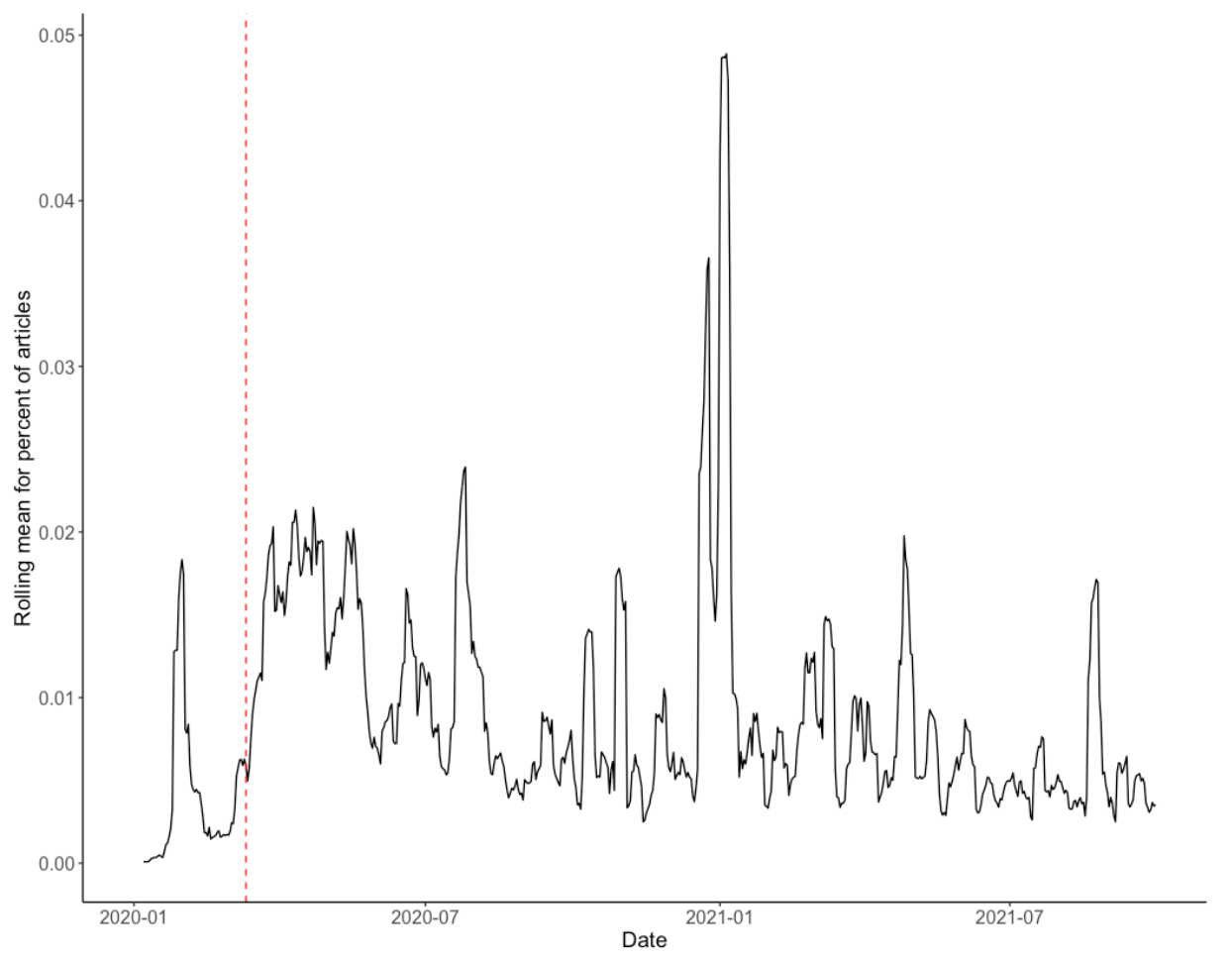

Figure 1: Rolling mean (weekly average) for the percent of total news articles (GDELT, 2021) mentioning (COVID) AND (worker OR employee) AND (seafood OR fisheries). The vertical red line denotes the date (11-March-2020) when the World Health Organization declared a global pandemic. 


\section{COVID-19 cases in the seafood industry}

The first reported COVID-19 outbreak in the US occurred in April 2020 at a processing facility in the Pacific Northwest. By May 2020, additional outbreaks had been reported across the country-from the Northeast to the Gulf Coast - primarily in seafood processing plants, but also at crawfish farms in Louisiana (Korban and Cherry, 2020). Cases of COVID-19 among seafood workers were reported or documented in 13 states, including Maine, New Hampshire, Massachusetts, Rhode Island, Pennsylvania, Virginia, Maryland, North Carolina, Louisiana, California, Oregon, Washington, and Alaska. Most cases and outbreaks across all food systems were observed in April and May of 2020 and have decreased since (Figs. 2,3). In the seafood industry, outbreaks and cases were more sporadic with peaks occurring between June-August 2020 and January-February 2021 (Fig. 2). With the seafood sector, outbreaks were documented in seafood plants and processing, seafood distributors, seafood wholesalers, aquaculture farms, and on vessels. As expected, most seafood-related COVID-19 cases and outbreaks occurred in coastal areas, with Alaska at the top of the list (Fig. 3).

Despite being a small part of the overall food system, the seafood industry accounted for $3.84 \%$ and $5.23 \%$ of all cases and outbreaks, respectively, although it is difficult to obtain exact employment numbers to compare industries. As an estimate, we used the total number of those employed in Food Manufacturing (NAICS 311000) in the US (May $2020=1,596,500)$ and the total number of people employed in Seafood Product Preparation and Packaging (NAICS 311700), which was 29,920 (U.S. Bureau of Labor Statistics, 2021). Thus, there was a two-order magnitude difference in employment for seafood versus the food system overall. As a rough estimate, we estimated there were 65 COVID-19 cases per 1000 workers in seafood versus 31 cases per 1000 for the overall food system. These numbers are difficult to compare to the general population as the cases identified here in food systems include only publicly documented cases or outbreaks for workplaces, as opposed to cases in general.
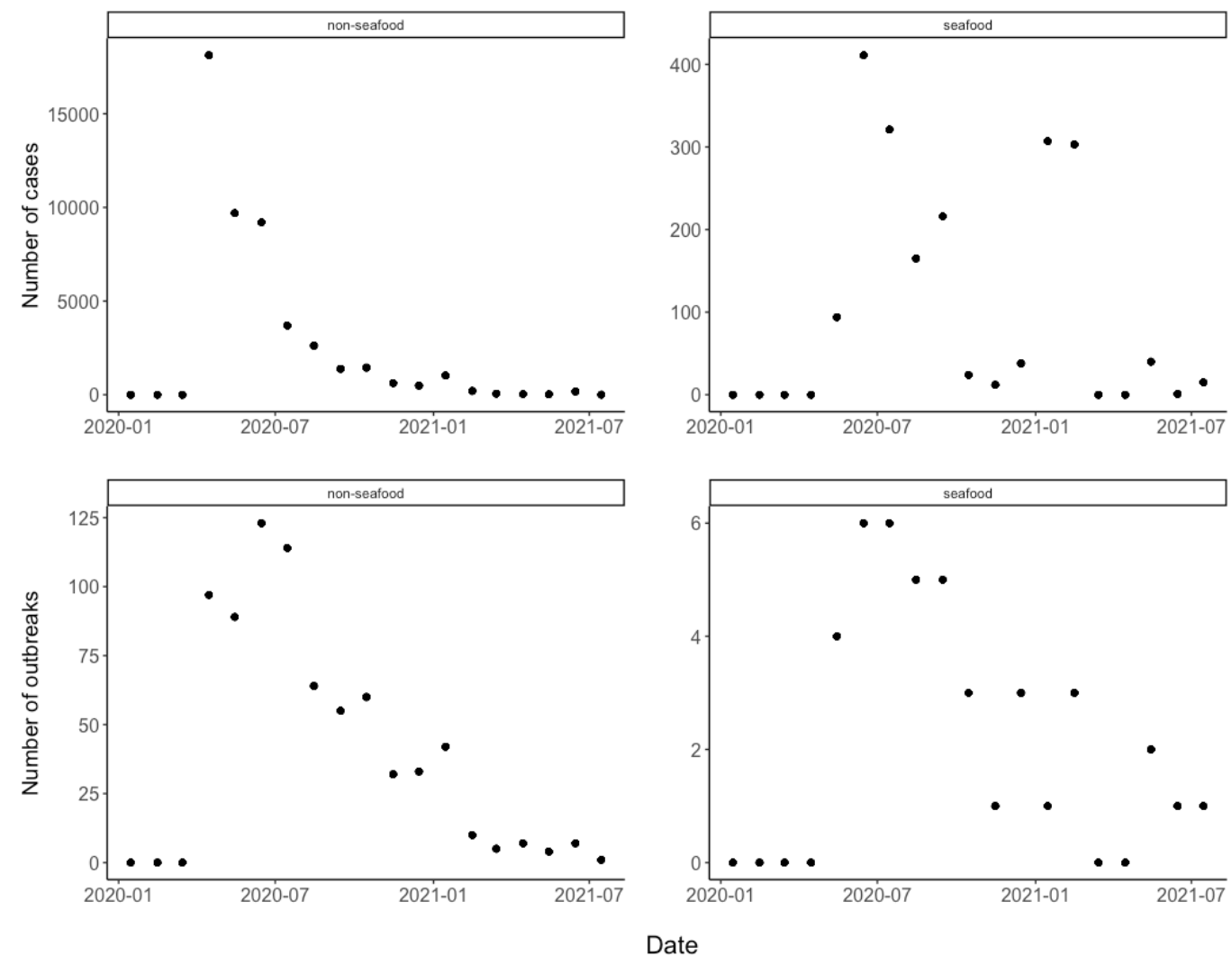

Figure 2: Total monthly COVID-19 cases and outbreaks for non-seafood and seafood workers. 


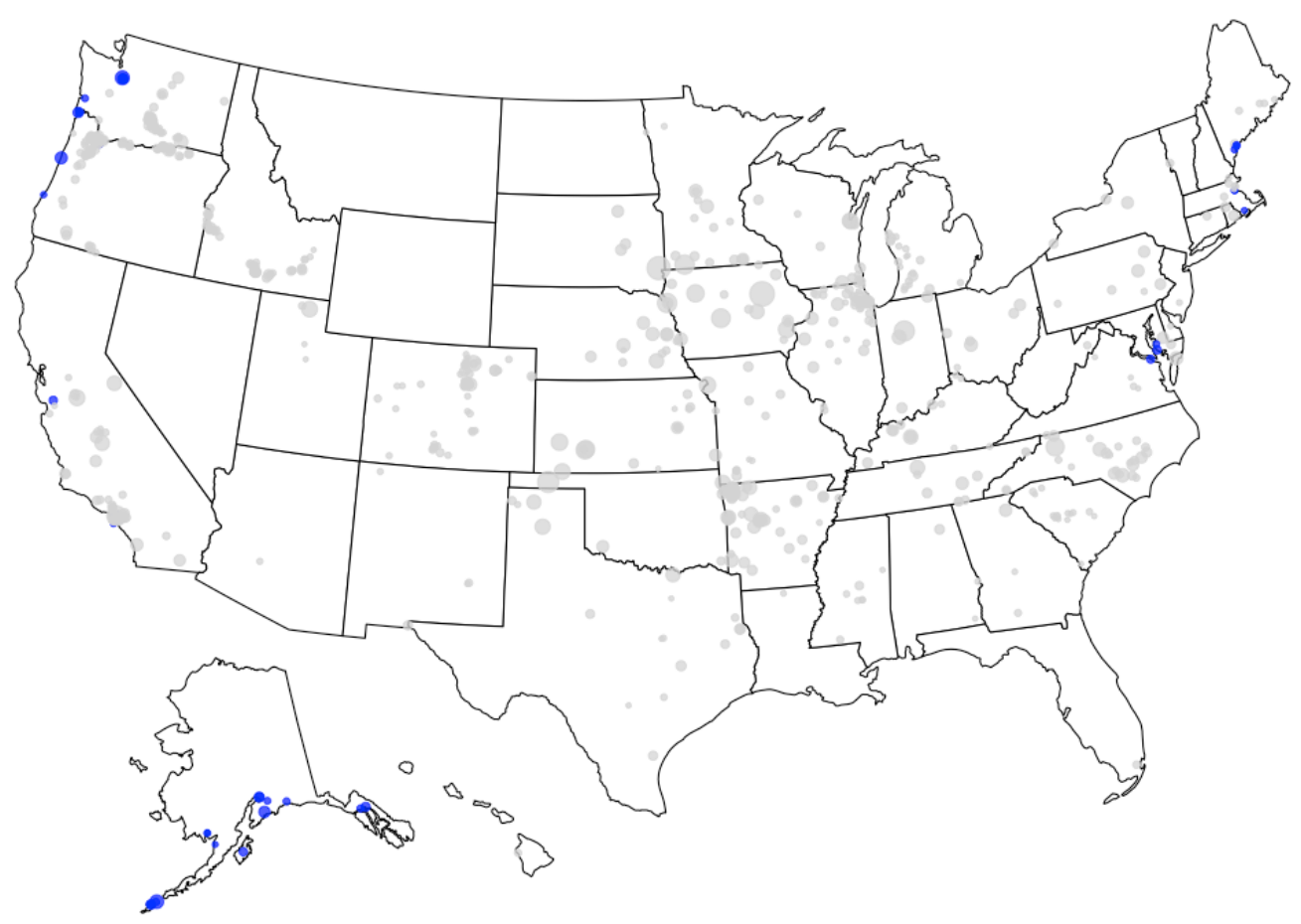

Figure 3: Spatial distribution of COVID-19 cases across the food system industry. The data is compiled from news articles from April 2020 to July 2021 (Douglas, 2021). The light grey points denote nonseafood cases and the blue points highlight seafood-related cases.

Table 1: Number of cases and outbreaks by food industry sector. The total number of workers for each sector (for May 2020) come from the U.S. Bureau of Labor Statistics with 1,596,500 and 29,290 employed in the overall food manufacturing (NAICS 311000) and seafood product preparation (NAICS 311700), respectively.

\begin{tabular}{|c|c|c|c|c|}
\hline Industry & Cases & Outbreaks & Cases per 1000 workers & Outbreaks per 1000 workers \\
\hline non-seafood & 48799 & 743 & 31.15 & 0.47 \\
\hline seafood & 1947 & 41 & 65.07 & 1.37 \\
\hline
\end{tabular}

\section{Discussion}

We found that both news coverage and documented COVID-19 cases showed similar patterns for seafood workers (Figs. 1,2). We found peaks in seafood-related COVID-19 cases during summer 2020 and in 
early 2021 (Fig. 2). These cases occurred primarily in coastal areas, with both the most cases, and cases per capita, occurring in Alaska (Fig. 3). Seafood-related COVID-19 cases occurred throughout the seafood value chain, including fishing vessels, seafood processors, and seafood distributors. News coverage showed similar patterns with a focus on outbreaks in processing facilities and vessels, but also documented indirect effects of the pandemic. These indirect effects included financial losses reported by fishers, aquaculturists, processors, and industry groups, in addition to changes in market demand, social distancing and travel restrictions, supply chain issues, and worker shortages.

In addition to COVID-19 outbreaks, deaths, and safety concerns, seafood workers faced several indirect effects from the COVID-19 pandemic such as loss of income, changes in consumer spending, and supply chain issues (Love et al., 2021b; Ross et al., 2021; Stoll et al., 2021; White et al., 2021). There was limited information on how the pandemic has affected seafood worker mental and physical health, and whether more accidents and fatalities arose because of the pandemic. However, more has been studied on the economic side, as the seafood industry has spent over \$50 million to reduce the spread of COVID-19 (Ross et al., 2021). Surveys have found that $82 \%$ of aquaculture farms were impacted by the pandemic and $20 \%$ of aquaculture farms reported pre-pandemic sales of $\$ 100,001-\$ 250,000$. At the beginning of the coronavirus pandemic, $70 \%$ of the North Central Aquaculture region farms and businesses reported loss of sales (Senten and Smith, 2020). For the fourth quarter of the 2020 year, focusing on mollusks and fish food, researchers found that $83 \%$ of respondents' farms had been impacted and $61 \%$ believed their farms would continue to be impacted in 2021 . The largest percentage of revenue lost was between $\$ 50,001$ $\$ 100,000$ and $\$ 10,000-\$ 25,000$ affecting $18 \%$ of fishers and seafood companies. The second highest amount of losses, at $15 \%$, was reported to be between $\$ 100,001-\$ 250,000.2 \%$ of fishers reported losing more than 1 million dollars in revenue. (Senten and Smith, 2020). News articles have reported lockdowns and curfews reducing the sizes of catches and forcing fishers to make less pay per day (Quallen, 2021). A survey was taken from Oceanic Strategies and reported by Alaska Journal of Commerce that interviewed 400 fishers (Welch, 2021). 98\% of fishers questioned claimed their businesses were "bashed" by the pandemic. $82 \%$ said fishing was their primary source of income, and $91 \%$ claimed they lost $15-100 \%$ of their revenues since January 2020. It was also reported that restrictions and measures to handle the pandemic had an immediate effect on the fishing market. Another survey reported by Katarina Zimmer of The Counter questioned 200 fishers, where $1 / 3$ claimed they were unsure they would be fishing in 3 years (Zimmer, 2021).

\section{Panel 1. Case studies of responding to the COVID-19 pandemic}

\begin{abstract}
Alaska
Alaska experienced the largest number of seafood-related COVID-19 outbreaks throughout the pandemic

(McKenney, 2021b). For example, on Aleutian island in Akutan, Trident Seafoods had to shut down due to 700 COVID-19 cases among workers in early 2021. Because the processing plant is on an island, no planes were able to fly for rescue, and there was limited supplies due to bad weather. This inhibited fishermen from unloading their boats, specifically of cod. The other large processing plant in this region is the Bering Sea, which has had outbreaks in Unalaska, Alaska. It is evident that Alaska had trouble managing the spread of the virus, as in early fall 2020,677 new cases were reported via 13 separate seafood processing facilities or processing vessel outbreaks (Porter et al.. 2021)
\end{abstract}

\section{New Bedford, Massachusetts}

The town of New Bedford, Massachusetts has been to the United States' wealthiest fishing port for almost two decades now. This port, specifically on pier 3, was the first location to set up a COVID-19 testing center. It opened in March 2020, while the rest of the country needed proof of symptoms or high-risk travel to report a case. Each crew, using the bubble system, would test in between fishing trips and was asked to quarantine for 2-3 days until test results would come back. With this system, only four vessels tested positive, and each was contained before an outbreak started. As of April 2021, New Bedford waterfront opened a Johnson and Johnson vaccine clinic. As of April 13th, over 1000 people were vaccinated and 1,200 individuals had appointments.

Alaska and the town of New Bedford, Massachusetts present an interesting comparison to highlight the variety of responses to the pandemic (Panel 1). Previous work, and this paper, have shown the high number of seafood-related COVID-19 cases in Alaska (Porter et al., 2021). Alaska produces $60 \%$ of the United States commercial fisheries with $40 \%$ of the nation's surface water (Liddel and Yencho, 2021; 
Resource Development Council, n.d.). In 2019, Alaska produced 5.6 billion pounds and $\$ 1.8$ billion, with the two largest commercial fisheries being Dutch Harbor and Aleutian Islands (Liddel and Yencho, 2021). As of Fall 2021, there have been 17 outbreaks, resulting in 848 cases in Alaska seafood alone. We hypothesize this is largely the result of several interconnected factors. First, seafood is a major industry in Alaska accounting for at least 1 million metric tons of food each year and over $\$ 1.8$ billion of labor income with 60,000 workers and greater than $\$ 5$ billion income for the U.S. economy (McDowell Group, 2017). Seafood processors reported their biggest challenge throughout the pandemic has been finding employers for their plants and that they spent over $\$ 50$ million on COVID-19 protocol in 2020, including food costs, coronavirus testing, and flying employees to Alaska and quarantining them in hotels before the season starts (White, 2020). Second, a lot of the labor for Alaskan fisheries is seasonal and involves migrant workers (Food and Agriculture Organization of the United Nations, 2020; Sánchez Pulla et al., 2021) Alaska's Department of Labor and Workforce Development published a report stating most of Alaska's nonresidents are employed seasonally, with the highest percentage of industries being manufacturing, which includes seafood processing. In 2019, 77\% of seafood's processing industry was made up of migrant workers, with $90 \%$ of workers being non-residents in the Aleutian Islands. In 2020, 91.2\% of the Aleutian Island workers were nonresidents (Alaska Department of Labor and Workforce Development, Research and Analysis Section, n.d.; Krieger and Whitney, 2021). Although a large amount of seafood processors in Alaska are non-resident or migrant workers, the H-2B program of the U.S. Department of Labor did not provide these workers with COVID-19 protection rules or measures (Sánchez Pulla et al., 2021). Cumulative rates of COVID-19 in Alaska for nonresidents is 24\% of resident cases, with nonresidents accumulating 5,145 cases and residents accumulating 124,568 cases. Between September 16 and October 27, there were 752 nonresident reported cases and 38,662 resident reported cases (Alaska Department of Health and Social Services, 2021). This concern is partially due to seafood processors failing to engage in proper Department of Labor COVID-19 safety measures. In March of 2021, it was reported that Copper River Seafoods violated COVID-19 safety precautions by failing to effectively screen employees for COVID-19, implement social distancing, prevent sick employees from work, and failure to input physical barriers for employees (Maguire, 2021). Third, in comparison to other states, Alaska either lagged, or did not implement, many social distancing restrictions (White and HébertDufresne, 2020) and has a low vaccination rate as of Fall 2021 (Dong et al., 2020). For example, on December 7, 2020, Copper River Seafoods was fined \$134,937 plus \$241,610 in fees for COVID-19 workplace safety violations after $70 \%$ of their employees contracted COVID-19 in an outbreak the employers took no additional protection measures (Field et al., 2021). And lastly, logistics in Alaska are difficult in terms of acquiring supplies or providing medical care.

We can contrast this with the town of New Bedford, Massachusetts which contains a massive shipping port where about 390 million pounds of fish pass through annually. The fish are typically distributed globally, with $1 / 3$ of the fish locally collected and $2 / 3$ of the fish come from international countries. It has been the United States' wealthiest fishing port for almost two decades now. The town and the state were more preemptive in responding to COVID-19 with a particular emphasis on the seafood sector. The town was one of the first to open both testing centers and vaccination sites for seafood workers specifically. Consequently, the town has seen only a limited number of cases and outbreaks in comparison to those in the Greater New Bedford area (New Bedford Health Department, 2021) (Panel 1). While New Bedford, Massachusetts has these sites available where other ports don't, the town was found to be behind the rest of Massachusetts state-wide vaccination rate average, with a wider gap for minority groups. As of November 2, 2021, the state-wide vaccination rate average was $68.1 \%$, while New Bedford's town average was 50.2\% ("COVID-19 Vaccine Equity Initiative," 2021). Within this town of New Bedford, $52.1 \%$ of the white population is vaccinated, $58.5 \%$ of the black population, $31.8 \%$ of the multiracial population, $55.2 \%$ of the Asian population, $34.1 \%$ of the American Indian/Alaska Native and 51.8\% of the Hispanic population. The vaccine hesitancy is reportedly due to misinformation and a lack of education from trustworthy individuals within identical communities (Spillane, 2021). There is also allegedly a lack of time in daily schedules and access to health care for certain individuals. Certain 
families have one individual working long day shifts, with the other partner working the opposite long shifts.

Available data and associated news coverage suggest inequity in terms of COVID-19 impacts and response due to occupational segregation based on gender, race, and immigration status within the seafood industry. A review of media coverage, as well as financial relief programs, policy, and research in response to the COVID-19 pandemic appear to prioritize participants in the commercial fishing and aquaculture sectors; however, available evidence suggests workers in the processing sector were more likely to be directly impacted by COVID-19 as outbreak events were concentrated in processing plants and at-sea processing vessels. It is crucial to note that twice as many people are employed in seafood processing and distribution than commercial fishing (NOAA Interactive Job Tool, 2017) and most of these workers are women, minorities, and immigrants (New American Research Fund, 2017; National Guestworkers Alliance, 2016). Black and Hispanic workers are more than twice as likely as white workers to be employed in animal processing (Hawkins, 2020) and foreign-born workers are known to play a particularly important role in the U.S. seafood processing sector (New American Economy Research Fund, 2017). In 2019, 61.7\% of workers in the seafood processing sector were foreign-born (New American Economy Research Fund, 2017). Furthermore, nearly 13,000 workers were granted temporary H-2B visas to process shrimp, crab, crawfish, catfish, salmon, pollock and other finfish, in addition to work in commercial fishing and aquaculture in 2021 ("Performance Data | U.S. Department of Labor," n.d.). A CDC analysis of data collected between March 1-May 31, 2020, found that Hispanic or Latino (72.8\%), non-Hispanic Black (6.3\%), and non-Hispanic Asian/Pacific Islander (4.1\%) workers accounted for a disproportionately high number of COVID-19 cases in food manufacturing and agriculture, including seafood processing (Waltenburg et al., 2021). Foreign-born, migrant, and undocumented workers face additional challenges in the workplace, such as language barriers, fear of reprisal from employers, hesitancy to report illness or seek healthcare, crowded transportation and housing arrangements, and lesser access to food security, healthcare, and relief programs (Bennett et al., 2020; Food and Agriculture Organization of the United Nations, 2020; National Guestwork Alliance, 2016; Waltenburg et al., 2020). As noted above, initial rounds of federal funding and financial relief programs targeted participants in the commercial fishing and aquaculture sectors, while funds to enhance workplace safety and protect workers in the seafood processing sector have yet to be disbursed (USDA, 2021).

The World Bank estimates that women account for $42 \%$ of the workforce in fishing and post-harvest activities such as seafood processing in developed countries, though the proportion of women is likely higher if unpaid and informal labor were included (International Bank for Reconstruction and Development/The World Bank, 2012; UN Women, 2020). It is suggested that women are differentially and disproportionately impacted by the COVID-19 pandemic, yet the extent to which the work, health, and wellbeing of women in the seafood industry have been affected by the pandemic is largely unknown (Briceño-Lagos and Monfort, 2020; Wabnitz et al., 2021). Women often fill low-wage, temporary, or casual labor positions that are more precarious and ineligible for government relief programs (Bennett et al., 2020; Briceño-Lagos and Monfort, 2020; Wabnitz et al., 2021), such as unemployment insurance and CARES Act funding. It has also been reported that mothers absorbed additional childcare responsibilities and reduced work hours because of closures of school and childcare facilities (Alon et al., 2020; Collins et al., 2020; "Gender Dimensions of the COVID-19 Pandemic," 2020), which in turn has the potential to affect fishing effort and landings. Furthermore, coping strategies adopted by women in fishing families include filling in as crew, producing value-added goods, engaging in shore-based employment, and direct marketing of seafood products ("Seafood Finder: Local Catch Network," 2021; Topness, 2021). Systematic, disaggregated data collection coupled with intersectional research is needed to better assess the direct and indirect effects of the COVID-19 pandemic across diverse groups of workers within the seafood industry. 
Most unanswered questions about how the pandemic has impacted fishers and the seafood industry pertain to the indirect effects on the industry. The first question to address is whether the issues of limited PPE on boats and urgent medical care nearby have affected seafood workers during the pandemic. The PPE that is worn on board is typically wet and can hold fish bacteria, allowing for exposure to occupational seafood respiratory allergy from biological and chemical agents that are associated with the work processes during processing, storing, preserving, and transporting seafood. This causes occupational asthma to be the most frequent work-related respiratory disease within the seafood industry. There are physical factors other than seafood that pose a risk for respiratory illness symptoms as well, including hypertonic saline aerosols from wet environments. The exposure to these allergens comes from the inhalation of dust, steam, and seafood proteins generated from cleaning, scraping, cooking, or drying areas where seafood residues are located (Jeebhay and Cartier, 2010). How did this impact breathing, respiratory illness contraction, and fishers developing more infections from the wet bacteria on their skin? There are also no reports on the number of accidents on board vessels during the timeline of the pandemic. Have accidents been happening more or less frequently within the seafood industry? Have seafood workers seen a difference in their stress levels, hours of sleep, and brain function because of the smaller crews? We hypothesize that mental and physical health as well as injury and mortality rates could all have suffered during the pandemic with smaller crew sizes and fewer workers on seafood processing lines, uncertainty about income, and changes in worker rules (Sorensen et al., 2020). However, smaller crew sizes and number of workers on seafood processing lines, as well as fishers leaving the industry, may have also led to decreases in injuries and fatalities. Several studies have now shown that some portions of the seafood sector have economically struggled because of the pandemic (Bennett et al., 2020; Smith et al., 2020; Stoll et al., 2021; White et al., 2021). Why did some fisheries rebound and quickly return to pre-COVID-19 demand and price levels, while others suffered significant loss and are showing signs of slow recovery? How will these markets and the overall seafood pipeline look different after the pandemic? Moving forward, it is crucial to understand the effect of other COVID-19 variants or other future diseases on seafood workers in general.

\section{Conclusions}

The COVID-19 pandemic is another example of a significant shock for the fisheries and seafood industries. The seafood industry has a long history of shocks, including extreme weather events, fishery collapses, trade disruptions, and more (Cottrell et al., 2019; Gephart et al., 2017, 2016; White et al., 2021). During any emerging event, relying on work on past shock events as well as ongoing data collection is critical. Because of a lack of timely information on the seafood sector, we had to rely on alternative data sources, including news articles and a user-contributed database of COVID-19 cases and outbreaks across the food sector. We hope this work serves as the foundation for other research on COVID-19 and seafood worker health and safety. Future work on COVID-19 and seafood could examine the disparate indirect effects of the pandemic and how they varied both in space and by sub-sector, how the seafood value chain has been changed overall, and how COVID-19 policies have affected seafood workers mental and physical health. Additional work could examine how differences in seafood distribution accelerated by the COVID-19 pandemic, including direct to consumer marketing (Smith et al., 2020; Stoll et al., 2021), may affect seafood workers moving forward. In addition, more general work around the role of shock events and the direct effects on all seafood workers is needed. This is important with increased demand for seafood products (Costello et al., 2020) occurring with an increased frequency and intensity of many rare events, such as hurricanes and heatwaves (Bender et al., 2010; Cai et al., 2014). 


\section{Acknowledgments}

E.R.W. was partially funded by a grant from the Gund Institute for Environment at the University of Vermont. We thank Leah Douglas at the Food and Environment Reporting Network for collating the data on COVID-19 cases within the U.S. food system.

\section{Code and Data Availability}

All code used in this paper is available at: https:/github.com/eastonwhite/covid seafood worker health For those interested in working with this data, please reach out to the corresponding author of this paper and directly to reporters at FERN.

\section{References}

Alaska Department of Health and Social Services, 2021. COVID-19 Cases Dashboard [WWW Document]. CVODI. URL https://alaskadhss.maps.arcgis.com/apps/MapSeries/index.html?appid=e1782f6c7784440694716b4112dd5588 (accessed 10.20.21).

Alaska Department of Labor and Workfoce Development, Research and Analysis Section, 2020. Seafood Processing Workforce and Waged by Borough or Census Area (CA), 2020 Alaska Statewide.

Alon, T., Doepke, M., Rumsey-Olmstead, J., Tertilt, M., 2020. The Impact of Covid-19 on Gender Equaity. Natl. Bur. Econ. Res.

Bender, M.A., Knutson, T.R., Tuleya, R.E., Sirutis, J.J., Vecchi, G.A., Garner, S.T., Held, I.M., 2010. Modeled Impact of Anthropogenic Warming on the Frequency of Intense Atlantic Hurricanes. Science 327, 454-458. https://doi.org/10.1126/science.1180568

Bennett, N.J., Finkbeiner, E.M., Ban, N.C., Belhabib, D., Jupiter, S.D., Kittinger, J.N., Mangubhai, S., Scholtens, J., Gill, D., Christie, P., 2020. The COVID-19 Pandemic, Small-Scale Fisheries and Coastal Fishing Communities. Coast. Manag. 1-11. https://doi.org/10.1080/08920753.2020.1766937

BLS, 2019. Census of Fatal Occupational Injuries (2000-Forward). All United States, Fishing. U.S. Department of Labor, Bureau of Labor Statistics, Washington, D.C.

Briceño-Lagos, N., Monfort, M.C., 2020. Why using a gender lens to analyse COVID-19 impacts on the seafood industry? [WWW Document]. WSI. URL https://womeninseafood.org/why-using-agender-lens-to-analyse-covid-19-impacts-on-the-seafood-industry/ (accessed 11.8.21).

Cai, W., Borlace, S., Lengaigne, M., van Rensch, P., Collins, M., Vecchi, G., Timmermann, A., Santoso, A., McPhaden, M.J., Wu, L., England, M.H., Wang, G., Guilyardi, E., Jin, F.-F., 2014. Increasing frequency of extreme El Niño events due to greenhouse warming. Nat. Clim. Change 5, 1-6. https://doi.org/10.1038/nclimate2100

Collins, C., Landivar, L.C., Ruppanner, L., Scarborough, W., 2020. COVID-19 and the gender gap in work hours. Gend. Work Org 28, 101-112.

Costello, C., Cao, L., Gelcich, S., Cisneros-Mata, M.Á., Free, C.M., Froehlich, H.E., Golden, C.D., Ishimura, G., Maier, J., Macadam-Somer, I., Mangin, T., Melnychuk, M.C., Miyahara, M., de Moor, C.L., Naylor, R., Nøstbakken, L., Ojea, E., O’Reilly, E., Parma, A.M., Plantinga, A.J., Thilsted, S.H., Lubchenco, J., 2020. The future of food from the sea. Nature. https://doi.org/10.1038/s41586-020-2616-y

Cottrell, R.S., Nash, K.L., Halpern, B.S., Remenyi, T.A., Corney, S.P., Fleming, A., Fulton, E.A., Hornborg, S., Johne, A., Watson, R.A., Blanchard, J.L., 2019. Food production shocks across land and sea. Nat. Sustain. 2, 130-137. https://doi.org/10.1038/s41893-018-0210-1

COVID-19 Vaccine Equity Initiative: Community-specific vaccination data | Mass.gov [WWW Document], 2021. URL https://www.mass.gov/info-details/covid-19-vaccine-equity-initiativecommunity-specific-vaccination-data (accessed 11.8.21).

Dong, E., Du, H., Gardner, L., 2020. An interactive web-based dashboard to track COVID-19 in real time. Lancet Infect. Dis. S1473309920301201. https://doi.org/10.1016/S1473-3099(20)30120-1 
Douglas, L., 2021. Mapping Covid-19 outbreaks in the food system [WWW Document]. Food Environ. Report. Netw. URL https://thefern.org/2020/04/mapping-covid-19-in-meat-and-food-processingplants/

FAO, 2020. How is COVID-19 affecting the fisheries and aquaculture food systems. FAO, Rome. https://doi.org/10.4060/ca8637en

Field, B., Jennings, P., Williamson, D., Roy, C., Pinder, J., 2021. Letter to AD Lamont [WWW Document]. URL https://www.documentcloud.org/documents/20495255-letter-to-ad-lamont (accessed 11.8.21).

Food and Agriculture Organization of the United Nations, 2020. Migrant workers and the COVID-19 pandemic |Policy Support and Governance| Food and Agriculture Organization of the United Nations [WWW Document]. URL https://www.fao.org/policy-support/tools-andpublications/resources-details/en/c/1270461/ (accessed 10.11.21).

GDELT, 2021. The GDELT Project.

Gender Dimensions of the COVID-19 Pandemic [WWW Document], 2020. . World Bank Group. URL https:/openknowledge.worldbank.org/bitstream/handle/10986/33622/Gender-Dimensions-of-theCOVID-19-Pandemic.pdf\%20?sequence=1\&isAllowed=y\%20(2020) (accessed 11.8.21).

Gephart, J.A., Cottrell, R.S., Froehlich, H., Nussbaumer, E., Stoll, J.S., White, E., 2020. Covid-19 Seafood Impacts. https://doi.org/10.5281/ZENODO.3866189

Gephart, J.A., Deutsch, L., Pace, M.L., Troell, M., Seekell, D.A., 2017. Shocks to fish production: Identification, trends, and consequences. Glob. Environ. Change 42, 24-32. https://doi.org/10.1016/j.gloenvcha.2016.11.003

Gephart, J.A., Pace, M.L., 2015. Structure and evolution of the global seafood trade network. Environ. Res. Lett. 10, 125014. https://doi.org/10.1088/1748-9326/10/12/125014

Gephart, J.A., Rovenskaya, E., Dieckmann, U., Pace, M.L., Brännström, Å., 2016. Vulnerability to shocks in the global seafood trade network. Environ. Res. Lett. 11, 035008. https://doi.org/10.1088/1748-9326/11/3/035008

Hawkins, D., 2020. Differential occupational risk for COVID-19 and other infection exposure according to race and ethnicity. Am. J. Ind. Med. 10.1002/ajim.23145. https://doi.org/10.1002/ajim.23145

International Bank for Reconstruction and Development/The World Bank, 2012. Hidden Harvest: The Global Contribution of Capture Fisheries [WWW Document]. URL https://documents1.worldbank.org/curated/en/515701468152718292/pdf/664690ESW0P1210120 HiddenHarvest0web.pdf (accessed 11.8.21).

Jeebhay, M.F., Cartier, A., 2010. Seafood workers and respiratory disease: an update. Curr. Opin. Allergy Clin. Immunol. 10, 104-113. https://doi.org/10.1097/ACI.0b013e3283373bd0

Knight, C.J., Burnham, T.L.U., Mansfield, E.J., Crowder, L.B., Micheli, F., 2020. COVID-19 reveals vulnerability of small-scale fisheries to global market systems. Lancet Planet. Health 4, e219. https://doi.org/10.1016/S2542-5196(20)30128-5

Korban, D., Cherry, D., 2020. COVID-19 cases in the seafood, fisheries and processing industry continue to rise | Intrafish [WWW Document]. Intrafish Latest Seaf. Aquac. Fish. News. URL https://www.intrafish.com/analysis/covid-19-cases-in-the-seafood-fisheries-and-processingindustry-continue-to-rise/2-1-812784 (accessed 11.16.21).

Krieger, R., Whitney, S., 2021. Nonresidents Working in Alaska - 2019.

Liddel, M., Yencho, M. (Eds.), 2021. Fisheries of the United States - 2019.

Love, D.C., Allison, E.H., Asche, F., Belton, B., Cottrell, R.S., Froehlich, H.E., Gephart, J.A., Hicks, C.C., Little, D.C., Nussbaumer, E.M., Pinto da Silva, P., Poulain, F., Rubio, A., Stoll, J.S., Tlusty, M.F., Thorne-Lyman, A.L., Troell, M., Zhang, W., 2021a. Emerging COVID-19 impacts, responses, and lessons for building resilience in the seafood system. Glob. Food Secur. 28, 100494. https://doi.org/10.1016/j.gfs.2021.100494

Love, D.C., Allison, E.H., Asche, F., Belton, B., Cottrell, R.S., Froehlich, H.E., Gephart, J.A., Hicks, C.C., Little, D.C., Nussbaumer, E.M., Pinto da Silva, P., Poulain, F., Rubio, A., Stoll, J.S., Tlusty, M.F., Thorne-Lyman, A.L., Troell, M., Zhang, W., 2021b. Emerging COVID-19 impacts, 
responses, and lessons for building resilience in the seafood system. Glob. Food Secur. 28, 100494. https://doi.org/10.1016/j.gfs.2021.100494

Love, D.C., Asche, F., Conrad, Z., Young, R., Harding, J., Nussbaumer, E.M., Thorne-Lyman, A.L., Neff, R., 2020. Food Sources and Expenditures for Seafood in the United States. Nutrients 12, 1810. https://doi.org/10.3390/nu12061810

Lucas, D.L., Kincl, L.D., Bovbjerg, V.E., Lincoln, J.M., Branscum, A.J., 2014. Work-related traumatic injuries onboard freezer-trawlers and freezer-longliners operating in Alaskan waters during 20012012. Am. J. Ind. Med. 57, 826-836. https://doi.org/10.1002/ajim.22310

Maguire, S., 2021. 2 Alaska seafood processing plants faced big fines for alleged COVID-19 workplace safety violations, then the Department of Labor commissioner stepped in [WWW Document]. https://www.alaskasnewssource.com. URL https://www.alaskasnewssource.com/2021/03/03/2alaska-seafood-processing-plants-faced-big-fines-for-alleged-covid-19-workplace-safetyviolations-then-the-dept-of-labor-commissioner-stepped-in/ (accessed 10.20.21).

Maine Coast Fishermen's Association: Covid19 Resources [WWW Document], 2021. . MCFA. URL https://www.mainecoastfishermen.org/covidresources (accessed 11.16.21).

McDowell Group, 2017. The Economic Value of Alaska's Seafood Industry [WWW Document]. McDowell Group. URL https:/www.mcdowellgroup.net/wp-content/uploads/2017/10/akseadfood-impacts-sep2017-final-digital-copy.pdf (accessed 10.7.21).

National Guestwork Alliance, 2016. Raising the Floor for Supply Chain Workers: Perspective from U.S. Seafood Supply Chains [WWW Document]. ILO. URL https://www.ituccsi.org/IMG/pdf/nga_raising_the_floor_for_supply_chain_workers_2016.pdf (accessed 11.15.21).

New Bedford Health Department, 2021. Coronavirus/COVID-19 Information - Health Department - City of New Bedford Official Website [WWW Document]. URL https://www.newbedfordma.gov/health-department/coronavirus/ (accessed 11.8.21).

NOAA, 2021. Commerce Secretary Announces Allocation of $\$ 300$ Million in CARES Act Funding | NOAA Fisheries [WWW Document]. NOAA. URL https://www.fisheries.noaa.gov/featurestory/commerce-secretary-announces-allocation-300-million-cares-act-funding (accessed 11.16.21).

OHS, 2020. The CDC Issues COVID-19 Guidance for Seafood Processing Workers - [WWW Document]. Occup. Health Saf. URL https://ohsonline.com/articles/2020/07/01/the-cdc-issuescovid19-guidance-for-seafood-processing-workers.aspx (accessed 11.16.21).

Performance Data | U.S. Department of Labor [WWW Document], n.d. URL https://www.dol.gov/agencies/eta/foreign-labor/performance (accessed 11.8.21).

Porter, K., Ramaswamy, M., Koloski, T., Castrodale, L., McLaughlin, J., 2021. COVID-19 Among Workers in the Seafood Processing Industry: Implications for Prevention Measures - Alaska, March-October 2020. MMWR 70, 622-626. https://doi.org/10.15585/mmwr.mm7017a4

Quallen, B., 2021. How COVID-19 Affects the Fishing Industry. BORGEN. URL https://www.borgenmagazine.com/fishing-industry/ (accessed 10.5.21).

Reiley, L., 2020. Commercial fishing industry in free fall as restaurants close, consumers hunker down and vessels tie up. Wash. Post.

Resource Development Council, n.d. Alaska's Fishing Industry [WWW Document]. URL https://www.akrdc.org/fisheries (accessed 10.5.21).

Ross, W., Jacobs, Dr.N., Oliver, C., 2021. NOAA Fisheries Updated Impact Assessment of the COVID19 Crisis on the U.S. Commercial Seafood and Recreational For-Hire/Charter Industries: National Snapshot, January-July 2020 [WWW Document]. NOAA Fish. URL https://media.fisheries.noaa.gov/2021-02/Updated-COVID-19-Impact-Assessment-webready.pdf

Sánchez Pulla, V., Ahmed, T., Gaddy, B., Perez Uribe Guinassi, L., Molina Acosta, C., Sorensen, S., Tambe, A., 2021. COVID-19 protections not offered to migrant seafood workers [WWW Document]. AP NEWS. URL https://apnews.com/article/immigration-coronavirus-pandemiclifestyle-travel-philanthropy-3ca3dc30b3d1f315b9c6661043408d40 (accessed 10.11.21). 
Seafood Finder: Local Catch Network [WWW Document], 2021. . Local Catch. URL https://finder.localcatch.org/ (accessed 11.8.21).

Senten, J. van, Smith, M., 2020. Impacts of COVID-19 on U.S. aquaculture, aquaponics, and allied businesses [WWW Document]. Va. Tech. URL https:////www.arec.vaes.vt.edu/content/arec_vaes_vt_edu/en/arec/virginiaseafood/research/Impacts_of_COVID19.html (accessed 10.5.21).

Smith, S.L., Golden, A.S., Ramenzoni, V., Zemeckis, D.R., Jensen, O.P., 2020. Adaptation and resilience of commercial fishers in the Northeast United States during the early stages of the COVID-19 pandemic. PLOS ONE 15, e0243886. https://doi.org/10.1371/journal.pone.0243886

Sorensen, J., Echard, J., Weil, R., 2020. From Bad to Worse: The Impact on COVID-19 on Commercial Fisheries Workers. Taylor Francis Group 4. https://doi.org/10.1080/1059924X.2020.1815617

Spillane, J., 2021. Getting vaccines to New Bedford's Latino neighborhoods [WWW Document]. New Bedford Light. URL http://newbedfordlight.org/getting-vaccines-to-new-bedfordsundocumented-workers-jack-spillane-column-covid-19/ (accessed 11.8.21).

Stoll, J.S., Harrison, H.L., De Sousa, E., Callaway, D., Collier, M., Harrell, K., Jones, B., Kastlunger, J., Kramer, E., Kurian, S., Lovewell, M.A., Strobel, S., Sylvester, T., Tolley, B., Tomlinson, A., White, E.R., Young, T., Loring, P.A., 2021. Alternative Seafood Networks During COVID-19: Implications for Resilience and Sustainability. Front. Sustain. Food Syst. 5, 614368. https://doi.org/10.3389/fsufs.2021.614368

Syron, L., Lucas, D., Bovbjerg, V., Case, S., Kincl, L., 2018. Occupational traumatic injuries among offshore seafood processors in Alaska, 2010-2015. J Saf. Res 66, 169-178. https://doi.org/10.1016/j.jsr.2018.07.008

Topness, E., 2021. In Alaska Fisheries, COVID-19 May Intensify Gender Inequality | Pulitzer Center [WWW Document]. Pulitzer Cent. URL https://pulitzercenter.org/stories/alaska-fisheries-covid19-may-intensify-gender-inequality

UN Women, 2020. Turning Promises Into Action: Gender Equality in the 2030 Agenda for Sustainable Development [WWW Document]. UNFCCC. URL https://unfecccop24.streamworld.de/sites/default/files/2020-07/ede0289a-def1-4afe-a0ca-7efec4fd9246.pdf (accessed 11.8.21).

U.S. Bureau of Labor Statistics, 2021. Seafood Product Preparation and Packaging - May 2020 OEWS Industry-Specific Occupational Employment and Wage Estimates [WWW Document]. URL https://www.bls.gov/oes/2020/may/naics4_311700.htm (accessed 11.8.21).

USDA, 2021. USDA Invests $\$ 700$ million to Provide Relief to Small Producers, Processors, Distributors, Farmers Markets and Seafood Processing Vessels and Processors Impacted by COVID-19 [WWW Document]. US Dep. Agric. URL https://www.usda.gov/media/pressreleases/2021/09/09/usda-invests-700-million-provide-relief-small-producers-processors (accessed 11.15.21).

Wabnitz, C.C.C., Blasiak, R., Harper, S., Jouffray, J.-B., Tokunaga, K., Norström, A.V., 2021. Gender Dimensions of Ocean Risk and Resilience in SIDS and Coastal LDCS [WWW Document]. Ocean Risk Resil. Action Alliance. URL https:/oceanrisk.earth/documents/ORRAA-Genderand\%20ocean-risk.pdf (accessed 11.8.21).

Waltenburg, M.A., Rose, C.E., Victoroff, T., Butterfield, M., Dillaha, J.A., Heinzerling, A., Chuey, M., Fierro, M., Jervis, R.H., Fedak, K.M., Leapley, A., Gabel, J.A., Feldpausch, A., Dunne, E.M., Austin, C., Pedati, C.S., Ahmed, F.S., Tubach, S., Rhea, C., Tonzel, J., Krueger, A., Crum, D.A., Vostok, J., Moore, M.J., Kempher, H., Scheftel, J., Turabelidze, G., Stover, D., Donahue, M., Thomas, D., Edge, K., Gutierrez, B., Berl, E., McLafferty, M., Kline, K.E., Martz, N., Rajotte, J.C., Julian, E., Diedhiou, A., Radcliffe, R., Clayton, J.L., Ortbahn, D., Cummins, J., Barbeau, B., Carpenter, S., Pringle, J.C., Murphy, J., Darby, B., Graff, N.R., Dostal, T.K.H., Pray, I.W., Tillman, C., Rose, D.A., Honein, M.A., 2020. Coronavirus Disease among Workers in Food Processing, Food Manufacturing, and Agriculture Workplaces - Volume 27, Number 1-January 2021 - Emerging Infectious Diseases journal - CDC 27. https://doi.org/10.3201/eid2701.203821 
medRxiv preprint doi: https://doi.org/10.1101/2021.11.16.21266427; this version posted November 17, 2021. The copyright holder for this preprint (which was not certified by peer review) is the author/funder, who has granted medRxiv a license to display the preprint in perpetuity.

It is made available under a CC-BY 4.0 International license .

Welch, L., 2021. FISH FACTOR: Survey reveals COVID-19 impacts for fishermen in 2020. Alsk. J. Commer.

White, C., 2020. Alaska's seafood processors hit hard by COVID-19 costs [WWW Document]. URL https://www.seafoodsource.com/news/supply-trade/covid-19-squeezing-alaska-seafoodprocessors (accessed 10.20.21).

White, E.R., Froehlich, H.E., Gephart, J.A., Cottrell, R.S., Branch, T.A., Agrawal Bejarano, R., Baum, J.K., 2021. Early effects of COVID-19 on US fisheries and seafood consumption. Fish Fish. 22, 232-239. https://doi.org/10.1111/faf.12525

White, E.R., Hébert-Dufresne, L., 2020. State-level variation of initial COVID-19 dynamics in the United States: The role of local government interventions. PLoSONE 14.

https://doi.org/10.1371/journal.pone.0240648

Zimmer, K., 2021. The pandemic could change U.S. fisheries forever. Will it be for better or for worse? The Counter. 